\title{
Peran Nitrogen Oksida pada Infeksi
}

\author{
Eka Gunawijaya, Arhana BNP
}

\begin{abstract}
Nitrogen oksida (NO) merupakan molekul kimia reaktif, disintesis dari L-Arginin dengan bantuan NO synthase (NOS) dan ko-faktor. Aktifitas biologis NO terbatas dekat tempat biosintesisnya, karena waktu paruh yang singkat. Nitrogen oksida menyebabkan relaksasi otot polos, menghambat agregasi dan adhesi trombosit, serta menghambat proliferasi sel. Otot polos yang dipengaruhi ialah otot polos vaskular, traktus respiratorius, gastrointestinal, dan uterus. Relaksasi otot polos vaskular terjadi setelah sintesis sel endotel vaskular, sedangkan yang non vaskular melalui perannya sebagai neurotransmiter non adrenergik non kolinergik.

Dalam proses imunologis, NO dihasilkan oleh sel yang terpapar infeksi. Meliputi sel makrofag, sel neutrofil, sel Kupffer, sel hepatosit, sel astrosit dan mikroglial, sel kondrosit, sel otot polos vaskular, dan sel otot jantung. Pada keadaan infeksi Nitrogen oksida disintesis dalam jumlah besar. Nitrogen oksida yang dihasilkan bersifat sitotoksik terhadap sel target, mikroorganisme patogen, dan juga pada sel tubuh normal. Inhibitor enzim NOS dan guanilat siklase bisa mengatasi sepsis, tetapi harus diberikan dini sebelum terjadi syok septik berkepanjangan. Inhibitor tersebut meliputi: deksametason, L-NAME, metilin blue, yomogin, aminoguanidin, econazol, dan indometasin. Nitrogen oksida juga berperan menimbulkan kerusakan jaringan dan organ akibat terapi reoksigenasi pada syok septik yang mengalami hipoksia.
\end{abstract}

Kata kunci: Nitrogen oksida - nitrogen oxyde synthase - neurotrasmitter

$\mathcal{R}$

adikal bebas nitrogen oksida atau nitrit oksida merupakan molekul kimia reaktif pada otot polos, menyebabkan vasodilatasi dan relaksasi otot polos organ tubuh lain., ${ }^{1,2}$ Berdasarkan efek vasodilator tersebut, NO dipakai sebagai preparat anti angina. ${ }^{3,4}$ Selain itu NO juga berperan dalam proses imunologis, di antaranya dihasilkan oleh sel makrofag jaringan, akibat aktifasi berbagai sitokin dan endotoksin bakteri patogen, ${ }^{5}$ yang mampu merusak sel target atau sel bakteri melalui perannya sebagai bahan sitotoksik. ${ }^{6,7}$

Sejak tahun 1987 penelitian tentang NO mulai banyak dilakukan, sebelumnya NO hanya dikenal

Alamat korespondensi:

Dr. Eka Gunawijaya, dr. Arhana BNPP Sp.A

Laboratorium/SMF Ilmu Kesehatan Anak Fakultas Kedokteran

Universitas Udayana/RS. Sanglah, Denpasar, Jl. Pulau Nias, Bali.

Telpon 0361-222141/222142, Fax. 0361-244038/24556. sebagai gas polutan, dihasilkan oleh mesin berbahan bakar minyak yang menyebabkan polusi asap dan hujan asam.

\section{Strukur dan Sifat Kimia Nitrogen Oksida}

Molekul NO dibentuk oleh 5 elektron nitrogen dan 6 elektron $\mathrm{O}$, sehingga ada 1 elektron yang tak berpasangan, menjadikan NO sebagai molekul reaktif yang bersifat radikal bebas. ${ }^{8}$ Nitrogen Oksida merupakan gas yang larut dalam air, dengan tingkat kelarutan 1-3 mmol/L (30-90 mg/L). Kadar biologis aktifnya berkisar 1-100 nmol/L bersifat lipofilik, sehingga mudah melewati sawar membran lipoprotein. Waktu paruh NO teramat pendek sekitar $£$ 3-5 detik, karena NO akan cepat dan spontan bereaksi dengan $\mathrm{O}_{2}$ membentuk ion nitrit $\left(\mathrm{NO}_{2}^{-}\right)$dan nitrat $\left(\mathrm{NO}_{3}^{-}\right)$, yang akhirnya diekskresi lewat ginjal. 
Aktifitas biologis nitrit lebih rendah dibandingkan NO, sedangkan nitrat relatif tidak mempunyai aktifitas biologis. ${ }^{6}$ Akibat waktu paruhnya yang pendek itu, NO hanya memiliki aktifitas biologis di sekitar tempat biosintesisnya saja.

Sebagai contoh sintesis NO di sel endotel vaskular, hanya mengakibatkan relaksasi otot polos vaskular di dekatnya. Reaksi kimia $\mathrm{NO}$ dan $\mathrm{O}_{2}$ membentuk ion nitrit dan nitrat sebagai berikut:

$$
\begin{aligned}
& 2 \mathrm{NO}+\mathrm{O}_{2} \rightarrow 2 \mathrm{NO}_{2} \rightarrow \underset{2}{\downarrow} \mathrm{N}_{4} \mathrm{O}_{4} \\
& \mathrm{H}_{2} \mathrm{O}+\mathrm{N}_{2} \mathrm{O}_{4} \rightarrow \mathrm{NO}_{2}{ }^{-}+\mathrm{NO}_{3}{ }^{-}+2 \mathrm{H}^{+}
\end{aligned}
$$

Selain dengan $\mathrm{O}_{2}$, radikal bebas $\mathrm{NO}$ juga mudah bereaksi dengan molekul lain yang mempunyai elektron tak berpasangan, misalnya anion superoksida $\left(\mathrm{O}_{2}{ }^{-}\right)$dan ferrum. ${ }^{8}$ Berbagai molekul yang mengandung $\mathrm{O}_{2}$ di intra atau ekstraselular mampu mengkatalisasi oksidasi inaktif $\mathrm{NO}$ menjadi nitrat, di antaranya oksihemoglobin $\left(\mathrm{HbO}_{2}\right)$. Hemoglobin memiliki afinitas yang tinggi terhadap NO daripada CO.

\section{Biosintesis Dan Metabolisme Nitrogen Oksida}

Sintesis NO membutuhkan asam amino L-arginin sebagai bahan dasar (Gambar 1), dibantu oleh enzim NO sinthetase (NOS). Nicotinamide adenine dinucleotide phospate (NADPH) merupakan ko-faktor utama, berfungsi untuk mentransfer elektron pada 5 elektron oksidan L-arginin. Ko-faktor lainnya ialah tetrahydrobiopterin, flavin adenine dinucleotide (FAD), flavin mononucleotide (FMN), dan heme. $N^{G}$-hydroxi$L$-arginin dibentuk dari $L$-arginin sebelum membentuk NO dan L-sitrulin (Gambar 1).

Pada NOS juga terdapat ikatan heme (feroproto-
porfirin-IX). Fungsi heme (bagian $\mathrm{Fe}_{2}^{+}$) ialah mengikat dan mengaktifasi $\mathrm{O}_{2}$, mentransfer elektron, dan mengikat kembali NO yang terbentuk. Ikatan NO dengan heme yang terikat di NOS tersebut diduga merupakan mekanisme umpan balik biosintesis NO.?

Terdapat dua jenis enzim NOS, yaitu constitutive isoform of $N O$ synthase (c-NOS) dan inducible isoform of NO synthase (i-NOS). Enzim c-NOS dibutuhkan untuk proses fisiologis, sedangkan i-NOS diperlukan pada keadaan patologis. Stimuli yang meningkatkan kadar $\mathrm{Ca}_{2}{ }^{+}$intraselular dari $0,1 \mu \mathrm{mol}$ menjadi $1 \mu \mathrm{mol}$ akan mencetus sintesis NO. ${ }^{10}$

\section{Fisiologis Nitrogen Oksida}

Jenis NO yang berperan secara fisiologis dalam tubuh dihasilkan oleh sel endotel vaskular melalui aktifitas enzim c-NOS.

\section{Vasodilator}

Nitrogen Oksida merupakan relaksan kuat otot polos vaskular yang mengakibatkan vasodilatasi vena maupun arteri, namun lebih bersifat venodilator daripada arteriodilator. Penggunaan klinis NO sebagai vasodilator dikenal sebagai nitrovasodilator, di antaranya nitrogliserin, sodium nitroprusid, dan isoamil nitrit. ${ }^{3,4}$

Relaksasi otot polos vaskular disebabkan oleh aktifitas NO di sel endotel di sekitarnya. Diawali oleh stimuli di permukaan sel endotel, misalnya oleh bradikinin. (Gambar 2). Interaksi bradikinin dengan reseptor selektifnya (B) mencetus influks $\mathrm{Ca}^{2+}$ dari lumen ke intraselular endotel. Bahan lain yang menimbulkan hal sama ialah asetilkolin, histamin, dan serotonin. Faktor gerakan aliran darah dan impuls

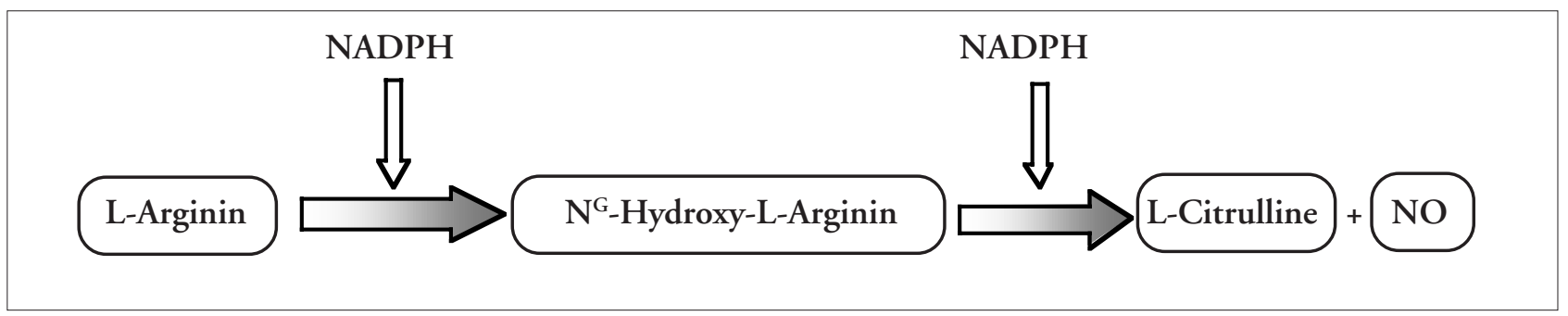

Gambar 1. Reaksi katalisasi asam amino L-Arginin menjadi nitrogen oksida9 


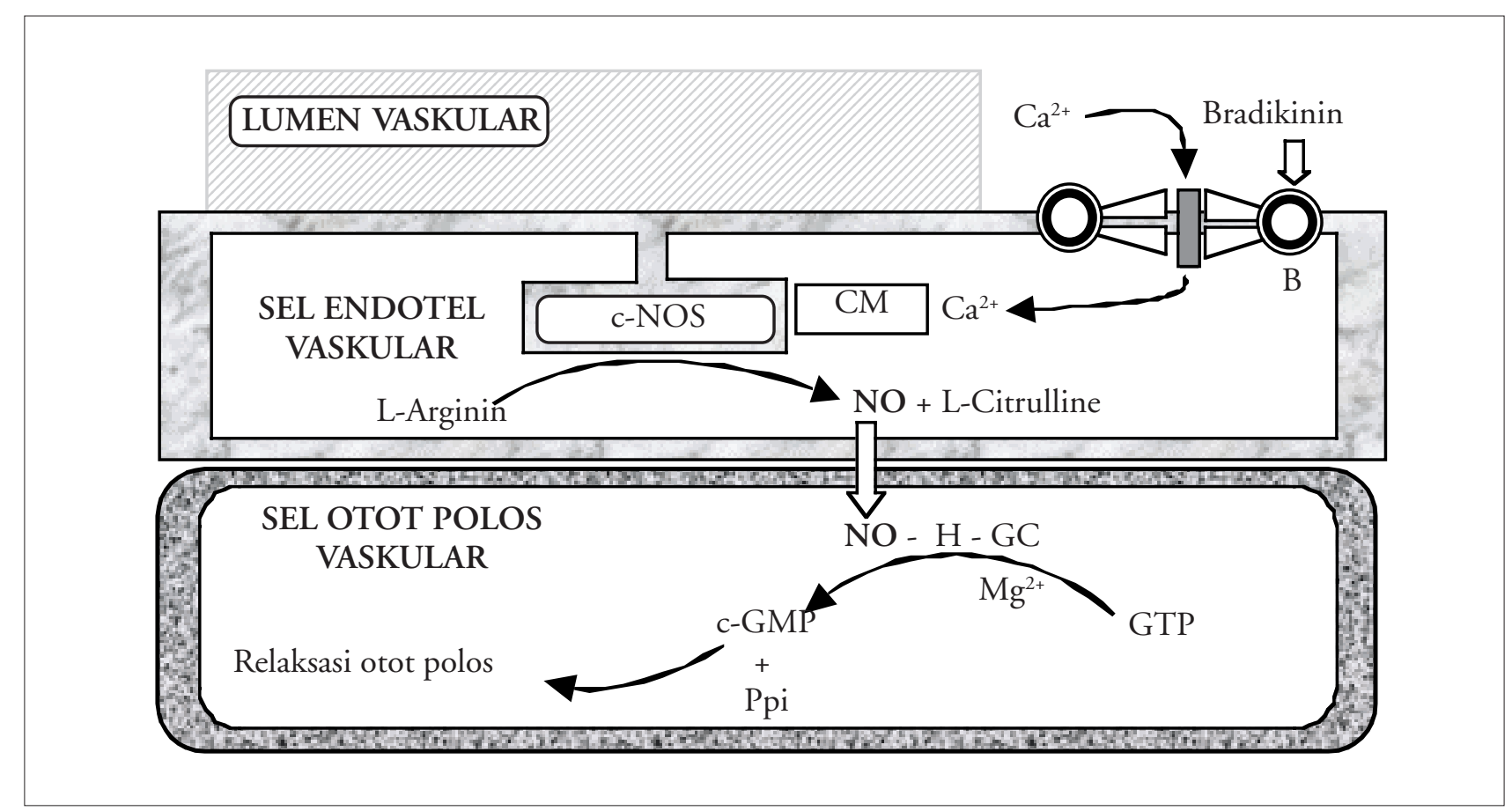

Gambar 2. Mekanisme relaksasi otot polos vaskular akibat NO. ${ }^{6}$

listrik tubuh juga berperan. $\mathrm{Ca}^{2+}$ yang masuk ke intraselular membentuk kompleks dengan calmodulin (CM) yang terikat di c-NOS, menyebabkan aktifasi c-NOS. Aktifitas c-NOS mengkatalisis asam amino L-Arginin menjadi NO dan L-Sitrulin. Nitrogen Oksida yang bersifat lipofilik segera berdifusi keluar sel endotel, melewati sawar membran endotel lalu masuk ke sel otot polos vaskular terdekat. Di dalam sel otot polos, NO membentuk kompleks dengan ion ferro $\left(\mathrm{Fe}^{2+}\right)$ dari heme $(\mathrm{H})$ yang terikat di sitosolik guanilat siklase (GC). Kompleks dengan bantuan magnesium $\left(\mathrm{Mg}^{2+}\right)$ mengaktifasi guanosin trifosfat (GTP) menjadi siklik-guanosin-3-5-monofosfat (cGMP) dan pirofosfat inorganik (Ppi). Akhirnya cGMP sebagai amplifier dan second massenger intraselular akan menurunkan kadar $\mathrm{Ca}^{2+}$ bebas intraselular dengan cepat dan menimbulkan inaktifasi rantai ringan kinase miosin. Kedua hal ini menyebabkan paralisis otot polos vaskular, sehingga terjadi vasodilatasi. ${ }^{1,6,11}$

\section{Neurotransmiter non adrenergic non cholinergic (NANC)}

Nitrogen oksida juga menyebabkan relaksasi otot polos non vaskular, di antaranya otot polos traktus respiratorius, ${ }^{2}$ traktus gastrointestinal, dan uterus. ${ }^{12}$ Aktifitas NO di otot polos non vaskular sebagai neurotransmiter non adrenergik non kolinergik. Oleh karena itu neuron NANC disebut pula neuron nitrosergis. Sebagai contoh ereksi penis disebabkan oleh vasodilatasi, namun vasodilatasi tersebut bukan akibat aktifitas NO di sel endotel vaskular melainkan melalui mekanisme neurotransmiter NANC seperti pada relaksasi otot polos non vaskular. ${ }^{6}$

\section{Neurotransmiter susunan saraf pusat dan traktus gastrointestinal}

Nitrogen oksida diduga berperan sebagai neurotransmiter di susunan saraf pusat, tetapi mekanismenya masih belum jelas. Diduga berperan dalam aktifitas neuron motorik eferen dan potensiasi jangka panjang fungsi memori. Ditemukannya enzim NOS di hipotalamus posterior diduga berhubungan dengan ekskresi oksitosin dan vasopresin, sedangkan di hipotalamus anterior berkaitan dengan ekskresi kortikotropin, growth hormon, dan thyroid stimulating hormon. ${ }^{6} \mathrm{Di}$ intestinum, enzim NOS ditemukan pada neuron NANC pleksus Auerbach dan pleksus misenterikus yang berperan dalam proses peristaltik. ${ }^{12}$ 


\section{Penghambat agregasi dan adhesi trombosit}

Nitrogen oksida menghambat proses agregasi trombosit, melalui aktifasi guanilat siklase (GC) sel trombosit. Selanjutnya c-GMP yang terbentuk akan mengganggu fungsi trombosit dengan cara menurunkan kadar $\mathrm{Ca}^{2+}$ sel trombosit. Sodium nitroprusid bekerja menghambat fungsi trombosit, sedangkan nitrogliserin tidak. Sodium nitroprusida melepas NO saat melekat pada trombosit, sedangkan nitrogliserin tidak. Selain mencegah agregasi trombosit, NO juga mencegah adhesi trombosit.

\section{Penghambat proliferasi sel}

Nitrogen oksida menghambat proliferasi sel di bawah otot polos vaskular. ${ }^{6}$ Kerusakan sel endotel menyebabkan terjadinya hiperplasia sel otot polos vaskular, oleh karena ketidakmampuan sel endotel vaskular mensintesis NO. Kelainan ini ditemukan pada arteriosklerosis, artritis imun, dan pascatindakan baloning angioplasti.

\section{Nitrogen Oksida Pada Infeks}

Nitrogen oksida yang dihasilkan oleh berbagai sel tubuh akibat paparan infeksi akan bersifat sitostatik pada sel dengan $\mathrm{pH}$ asam (sel target, mikroorganisme patogen).

\section{Sintesis Nitrogen Oksida pada Infeksi}

Terdapat dua sel yang berperan pada sintesis NO oleh sel makrofag, yaitu sel makrofag itu sendiri dan sel limfosit T. Proses aktifasi sel makrofag diawali oleh paparan komponen endotoksin bakteri pada sel makrofag (Gambar 3), ${ }^{5}$ sehingga makrofag melepaskan tumour necrosis factor (TNF). Tumour necrosis factor yang dilepaskan akan siap mempengaruhi sel makrofag lain yang sudah teraktifasi oleh sel limfosit T. Paparan endotoksin tersebut juga mengaktivasi sel limfosit $\mathrm{T}$, untuk melepaskan interferon- $\gamma$ (IFN- $\gamma$ ). Selanjutnya IFN- $\gamma$ akan siap mengaktivasi sel makrofag untuk mensintesis i-NOS. Maka dimulailah proses sintesis NO dalam sel makrofag yang teraktivasi. Sintesis ini diawali oleh ikatan IFN- $\gamma$ yang dilepaskan oleh sel limfosit $\mathrm{T}$ melalui reseptornya di permukaan sel makrofag. ${ }^{7}$ Ikatan ini mencetus sintesis i-NOS dalam sel makrofag, yang siap berperan dalam sintesis NO. Tumour necrosis factor) yang dilepaskan oleh sel makrofag lain akan berikatan dengan reseptornya di permukaan sel makrofag yang sudah mengandung iNOS tadi. Ikatan ini mengaktifasi i-NOS yang sudah terbentuk, dengan bantuan ko-faktor tetrahidrobiopterin terjadi reaksi katalisis asam amino L-arginin menjadi NO dan L-citrulline. Akhirnya NO akan dilepaskan, keluar dari sel makrofag.

Nitrogen oksida yang dihasilkan makrofag cenderung bersifat sitostatik daripada sitosidal, pada

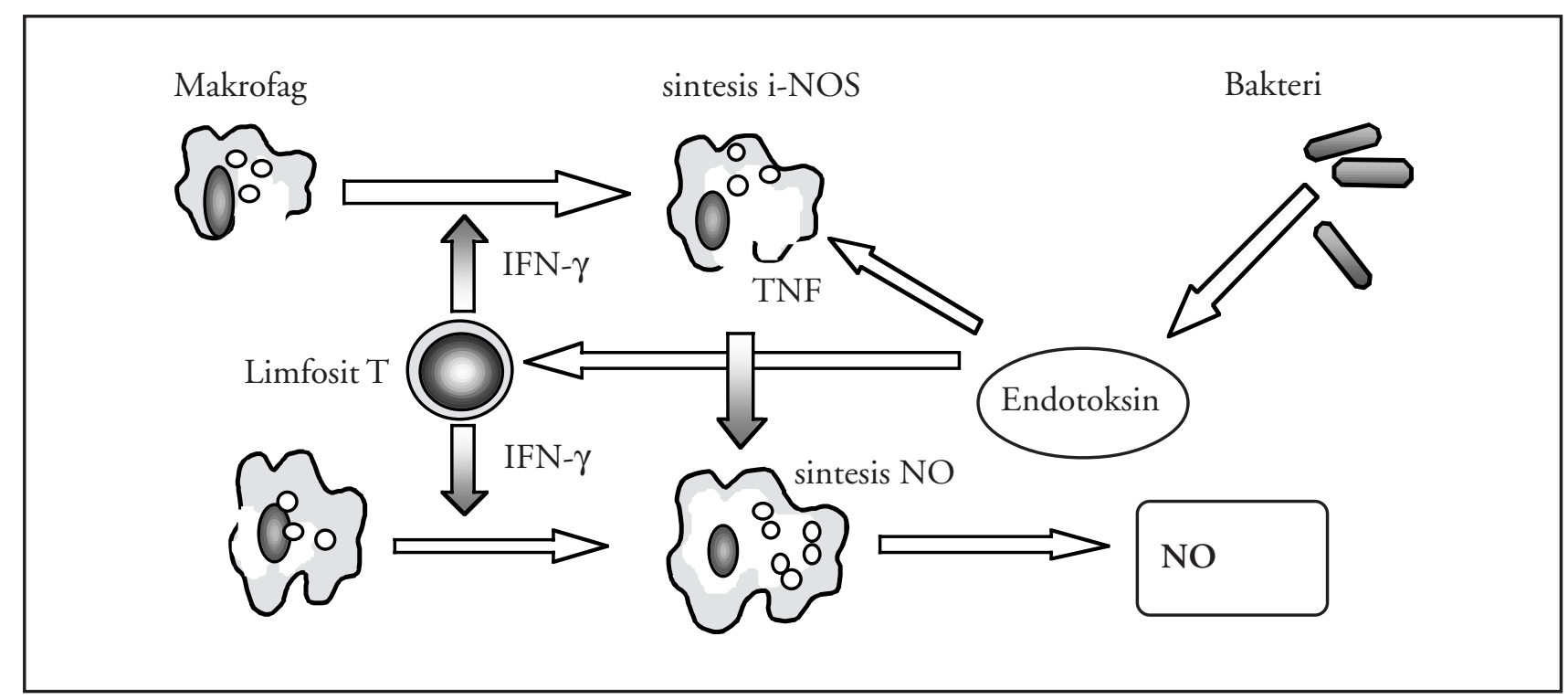

Gambar 3. Aktifasi Sel Makrofag Sebagai Pencetus Sintesis NO 5 
kadar yang amat tinggi akan bersifat sitosidal. ${ }^{6}$ Pada kadar NO tinggi akan berikatan dengan protein sel yang mengandung ferrum heme ataupun non-heme. Enzim respirasi selular (akonitase mitokondria, oksidoreduktase NADPH) merupakan protein yang mengandung ferrum heme, sehingga ikatan NO dengan enzim ini akan mengakibatkan gangguan respirasi selular. ${ }^{11}$ Semua itu menimbulkan gangguan fungsi dan proliferasi sel (sitostatik). Sedangkan pada kadar yang amat tinggi, NO tidak hanya berikatan dengan ferrum. Tapi akan mencegah ferrum keluar dari sel sehingga menyebabkan kerusakan sel (sitosidal). ${ }^{13}$

Selain makrofag, yang bisa menghasilkan NO sitotoksik akibat paparan infeksi ialah sel neutrofil, astrosit dan mikroglial, kondrosit, sel Kupffer, dan hepatosit. ${ }^{13}$ Sel otot polos vaskular juga dapat menghasilkan NO dalam jumlah besar, selain oleh sel endotelnya. Ditemukan aktifitas i-NOS dalam sel otot jantung pasien, karena itu diduga sel otot jantung juga dapat menghasilkan NO. ${ }^{14,15}$

\section{Nitrogen Oksida pada Sepsis}

Enzim c-NOS mencetus produksi NO dalam jumlah kecil yang hanya menimbulkan vasodilatasi sementara, sedangkan i-NOS mencetus produksi dalam jumlah besar dan mampu menimbulkan vasodilatasi hebat dan lama. ${ }^{11,16}$ Tampak perbedaaan kadar NO antara pasien sepsis dengan anak sehat, berdasarkan atas pengukuran kadar ion nitrit dan nitrat plasmanya (Tabel 1). ${ }^{16}$

Timbulnya syok septik/endotoksin disebabkan produksi NO langsung oleh sel otot polos vaskular. ${ }^{14,17,18}$ Diawali oleh paparan endotoksin dan sitokin yang dilepaskan sel limfosit T sitotoksik, yaitu interleukin-1 (IL-1) dan TNF. Interleukin-1 dan TNF mengaktifasi enzim i-NOS di dalam sel otot polos vaskular. Nitrogen Oksida yang dihasilkannya menyebabkan relaksasi otot polos vaskular itu sendiri. Tempat aktifitas biologis dan biosintesis tersebut mengakibatkan paralisis total dinding vaskular yang bersifat sistemik yang berlangsung lama. Mengakibatkan penurunan resistensi vaskular perifer dan tekanan darah yang sulit diatasi, dengan preparat vasokonstriktor sekalipun. ${ }^{10,11,17,18}$ Keadaan tersebut secara klinis tampak sebagai syok, yang mengakibatkan kegagalan fungsi multi organ. Pada pasien syok septik dengan kegagalan fungsi otot jantung ditemukan aktifitas i-NOS di dalam sel otot jantungnya, diduga menghasilkan NO yang menyebabkan relaksasi otot jantung dan bahkan merusak otot jantung itu sendiri sehingga menimbulkan kegagalan otot jantung. ${ }^{14}$

Telah diketahui bahwa preparat vasokonstriktor seringkali sulit mengatasi syok septik. Aktifasi i-NOS oleh endotoksin dan sitokin dapat dihambat dengan deksametason dengan dosis $3 \mathrm{mg} / \mathrm{kgBB}$ bolus intra vena. ${ }^{19}$ Terapi deksametason pada sepsis harus diberikan sejak dini. Deksametason tidak berefek bila diberikan pada saat telah terjadi syok septik lama karena telah terjadi kerusakan reseptor glukokortikoid akibat NO berjumlah besar pada saat syok. ${ }^{20}$ Inhibitor iNOS yang lain adalah $N^{G}$-monometyl-L-Arginine (LNAME) dosis $10 \mathrm{mg} / \mathrm{kgBB}$ dapat memulihkan kembali fungsi vaskular. ${ }^{14,19}$ L-NAME dapat pula diberikan dengan dosis $5 \mathrm{mg} / \mathrm{kgBB} / \mathrm{jam}$ selama 8 jam, ${ }^{21}$ sedangkan pemberian dengan dosis $1 \mathrm{mg} / \mathrm{kgBB} / \mathrm{jam}$ per drip infus tidak berefek. ${ }^{22}$ Methylline blue $1 \mathrm{mg} /$ $\mathrm{kgBB}$ sebagai inhibitor guanilat siklase menghambat aktifitas NO yang telah terbentuk, tetapi tidak menghambat sintesisnya. ${ }^{1,10,14}$ Methylline blue dapat meningkatkan tekanan sistolik, tekanan diastolik, dan tekanan arteri pasien sepsis, tetapi tidak dapat meningkatkan curah jantungnya. ${ }^{23}$ Yomogin yang berasal dari tumbuhan Artemisia princeps pampan juga bisa menghambat aktifitas i-NOS. ${ }^{24}$ Preparat lain yang menghambat enzim i-NOS ialah aminoguanidin 100 $\mathrm{mg} / \mathrm{kgBB}$, econazole $1 \mathrm{mg} / \mathrm{kgBB}$, dan indometasin 100 $\mathrm{mg} / \mathrm{kgBB} .^{25}$

Pemberian endotoksin lipopolisakarida (LPS) 10 $\mathrm{mg} / \mathrm{kgBB}$ intravena bolus akan mengakibatkan

Tabel 1. Kadar Ion Nitrit $\left(\mathrm{NO}_{2}^{-}\right)$dan Nitrat $\left(\mathrm{NO}_{3}^{-}\right) \mathrm{Plasma}^{16}$

\begin{tabular}{lcccc}
\hline \multirow{2}{*}{ Kelompok } & \multicolumn{3}{c}{ Kadar ion nitrit dan nitrat $(\mu \mathrm{mol} / \mathrm{L})$} \\
\cline { 3 - 5 } & & Rata-rata \pm SD & Nilai tengah & Rentang \\
\hline Sehat & $34,97 \pm 13,41$ & 35,2 & $10,1-60,4$ \\
Sepsis & tanpa syok & $126,22 \pm 85,83$ & 97,95 & $34,8-341,7$ \\
& syok & $582,22 \pm 384,82$ & 491,5 & $242,1-1230,4$ \\
\hline
\end{tabular}


penurunan tekanan darah yang cepat dan bertahan lama. Kadar c-GMP sel otot polos arteri pulmonal meningkat menjadi $140 \mathrm{pmol} / \mathrm{mL} 24$ jam setelah pemberian LPS, tetapi tidak terdapat perbaikan setelah 60 menit pemberian vasopresor norepinefrin intra vena. Keadaan ini bisa diatasi dengan preparat L-NAME, yang menurunkan kadar c-GMP menjadi $0,04 \mathrm{pmol} / \mathrm{mL}$ dalam 24 jam. ${ }^{26}$ Pada menit ke-60 pemberian LPS, i-NOS hanya ditemukan di aorta, sedangkan di menit ke-180 sudah ditemukan di beberapa jaringan tubuh lain. Terjadi aktifitas i-NOS pada jam ke-6 pemberian kombinasi IFN-g dan LPS, yang bertahan hingga jam ke-48 dengan puncaknya saat jam ke-12.9,11 Pernah diteliti pemberian LPS Escherisia coli $15 \mu \mathrm{g} / \mathrm{kgBB}$ intra vena. Pemberian diulangi 18 jam kemudian dengan dosis ditingkatkan 200-2.000 $\mu \mathrm{g} / \mathrm{kgBB}$, kemudian diperiksa tekanan perfusi arteri telinga dan ginjal, diamati fungsi kontraksi vaskular pada saat diberi norepinefrin, serta respons relaksasi kembali saat diberi metakolin dan sodium nitroprusid. Norepinefrin dan relaksan metakolin berefek di arteri telinga, tetapi tidak di arteri ginjal, sedangkan relaksan sodium nitroprusida sama efeknya baik di arteri telinga maupun ginjal; sehingga diduga LPS menyebabkan dilatasi arteri telinga, tetapi tidak menimbulkan dilatasi vaskular renal. ${ }^{11}$

Terapi reoksigenasi berlebihan pada syok septik yang mengalami hipoksia justru dapat berefek buruk bagi tubuh. Reoksigenasi berlebihan akan menyebabkan beredarnya sejumlah anion superoksidan $\left(\mathrm{O}^{2-}\right)$ dalam darah. Anion ini akan bereaksi dengan NO yang kadarnya tinggi saat terjadi syok septik, menghasilkan radikal bebas anion peroksinitrit (ONOO-) yang sitotoksik. Radikal bebas ini berpotensi menimbulkan peroksidasi lipid sehingga menyebabkan kerusakan jaringan dan organ yang sangat serius. ${ }^{8}$

\section{Kesimpulan}

Sejak tahun 1987 hingga dengan saat ini masih terus diteliti berbagai aspek peranan NO. Akibat paparan infeksi, NO disintesis dalam jumlah besar oleh beberapa sel imunologis dan sel tubuh. Nitrogen Oksida berperan sebagai bahan sitotoksik terhadap sel target, mikroorganisme patogen, dan juga pada sel tubuh normal. Pada suatu saat NO diperkirakan akan memegang peran penting dalam berbagai penanganan penyakit yang berkaitan dengan relaksasi otot-otot polos tubuh.

\section{Daftar Pustaka}

1. Schreiber MD. Methylene blue: NO Panacea. J Pediatr 1996; 129:790-3.

2. Finer N. Inhaled nitric oxide in neonates. Arch Dis Child 1997; 77:F81-4.

3. Notterman DA. Cardiovascular support-pharmacologic. Dalam: Holbrook PR, Penyunting. Textbook of pediatric critical care. Philadelphia: Saunders, 1993;288-311.

4. Carcillo JA. Management of pediatric septic shock. Dalam: Holbrook PR, Penyunting. Textbook of pediatric critical care. Philadelphia: Saunders, 1993;h.114-41.

5. Rook G. Cell mediated immune reactions. Dalam: Roitt IM, Brostoff J, Male DK, Penyunting. Immunology; edisi ke-3, St.Louis: Mosby, 1993; 8:1-16.

6. Ignarro LJ. Physiologic and pathophysiologic significance of nitric oxide. Dalam: Ayres SM, Grenvik A, Holbrook PR, Shoemaker WC, Penyunting. Textbook of critical care; edisi ke-3. Philadelphia: Saunders, 1995;209-15.

7. Rook G. Immunity to viruses, bacteria, and fungi. Dalam: Roitt IM, Brostoff J, Male DK, Penyunting. Immunology; edisi ke-3, St.Louis: Mosby, 1993;h.15.122.

8. Boveris A. Bichemistry of free radicals from electron to tissues. Medicina B Aires 1998; 58:350-6.

9. Hecker M, Cattaruzza M, Wagner AH. Regulation of inducible nitric oxide synthase gene expression in vascular smooth muscle cells. Gen Pharmacol 1999; 32:9-16.

10. Duke T, South M, Stewart A. Activation of the L-arginine nitric oxide pathway in severe sepsis. Arch Dis Child 1997; 76:203-9.

11. Koltai M, Guinot P, Hosford D, Braquet PG. Platelet activating factor in septic shock. Dalam: Ayres SM, Grenvik A, Holbrook PR, Shoemaker WC, Ed. Textbook of critical care; edisi ke-3. Philadelphia: Saunders, 1995; h.215-21.

12. Zicari A, Corrado G, Cavaliere M. Increased levels of prostaglandins and nitric oxide in esophageal mucosa of children with reflux esophagitis. JPGN 1998; 26:1949 .

13. Taverne J. Immunity to protozoa and worms. Dalam: Roitt IM, Brostoff J, Male DK, Penyunting. Immunology; edisi ke-3, St.Louis: Mosby, 1993;h.16.1-22.

14. Kumar A, Brar R, Wang P, dkk. Role of nitric oxide and c-GMP in human septic serum-induced depression of cardiac myocyte contractility. Am J Physiol 1999; 276:R265-76.

15. Hislop AA, Springall DR, Oliveira H, Pollock JS, Polak JM, Haworth SG. Endothelial nitric oxide synthase in hypoxic newborn porcine pulmonary vessels. Arch Dis Child 1997; 77:F16-22.

16. Shi Y, Li HQ, Shen CK, dkk. Plasma nitric oxide levels in newborn infants with sepsis. J Pediatr 1993; 123:435-8. 
Sari Pediatri, Vol. 2, No. 2, Agustus 2000

17. Stoclet JC, Muller B, Andriantsitohaina R, Kleschyov A. Overproduction of nitric oxide in pathophysiology of blood vessels. Biochemistry Mosc 1998; 63:826-32.

18. Hon WM, Khoo HE, Moochhala S. Nitric oxide in septic shock-directions for future therapy. Ann Acad Med Singapore $1998 ; 27: 414-21$.

19. Wang D, Wei J, Hsu K. Effects of nitric oxide synthase inhibitors on systemic hypotension, cytokines and inducible nitric oxide synthase expression, and lung injury following endotoxin administration in rats. J Biomed Sci 1999; 6:28-35.

20. Galigniana MD, Piwien PG, Assreuy J. Inhibition of glucocorticoid receptor binding by nitric oxide. Mol Pharmacol 1999; 55:317-23

21. Hussein Z, Beerahee M, Grover R, dkk. Pharmacokinetics of the nitric oxide synthase inhibitor L-NG-methylarginine hydrochloride in patients with septic shock. Clin Pharmacol Ther 1999; 65:1-9.

22. Avontuur JA, Boomsma F, Meiracker AH, Jong FA, Bruining HA. Endothelin-1 and blood pressure after inhibition of nitric oxide synthesis in human septic shock. Circulation 1999; 99:271-5.

23. Andresen M, Dougnac A, Diaz O, dkk. Use of methylene blue in patients with refractory septic shock: Impact on hemodynamics and gas exchange. J Crit Care 1998;13:164-8.

24. Ryu JH, Lee HJ, Jeong YS, Ryu SY, Han YN. Yomogin - An inhibitor of nitric oxide production in LPS activated macrophages. Arch Pharm Res 1998; 21:481-4.

25. Tunctan B, Uludag O, Altug S, Abacioglu N. Effects of nitric oxide synthase inhibition in lipopolysaccharide induced sepsis in mice. Pharmacol Res 1998; 38:405-11.

26. Scott WS, Nakayama DK. Escherichia coli lipopolysaccharide downregulates soluble guanilate cyclase in pulmonary artery smooth muscle. J Surg Res 1998; 80:309-14 